VIRUSES AND CELL

\title{
Partial sequencing and phylogenetic analysis of Soybean mosaic virus isolated in Ukraine
}

\author{
D. V. Sherepitko, I. G. Budzanivska, V. P. Polischuk, A. L. Boyko \\ Taras Shevchenko National University of Kyiv \\ 64, Volodymyrska Str., Kyiv, Ukraine, 01601 \\ supervirusok@gmail.com
}

\begin{abstract}
The aim of the present study is to compare the biological and molecular properties of Ukrainian soybean mosaic virus (SMV) isolates with those of known strains or isolates from other countries, and to trace their possible origin. The methods of mechanical inoculation, reverse transcription polymerase chain reaction, DNA sequencing and phylogenetic analysis have been used. Results. Five SMV isolates have been collected and biologically purified from breeding plots in Vinnitsa region of Ukraine. It has been found that all these isolates show the same reaction patterns when infecting 11 differential soybean cultivars. Phylogenetic analysis of sequences of the coat protein coding region and P1 coding region revealed strong genetic relationships between representative Ukrainian (UAlGr) and SMV-VA2 isolates which together were sorted in one clade with G2 strain. The investigation of sequence identity showed that different genomic regions of SMV were under different evolutionary constraints. Conclusions. SMV, isolated in Ukraine for the first time, belongs to the G2 strain group that is widespread in North America. The SMV isolates obtained in this work may be employed in the Ukrainian national breeding programs to create soybean with durable virus resistance.
\end{abstract}

Keywords: Soybean mosaic virus, Potyvirus, Glycine max, nucleotide sequences, phylogenetic analysis.

Introduction. Soybean mosaic virus (SMV) is a member of the Potyviridae family within the genus of Potyvirus, which is the largest group of plant viruses [1]. It is the most common and prevalent viral pathogen of soybean (Glycine max (L.) Merr.) worldwide. Symptoms induced by SMV include severe mosaic, mottling, rugosity and necrosis on the leaves of many soybean varieties [2]. Following seed transmission (1-68\%) or spread by aphid vector in non-persistent manner, the different SMV strains cause 10-50\% yield losses and seed quality deterioration in many soybean producing areas $[2,3]$. Furthermore SMV may induce much more severe damages of soybean when mix-infected with other virus pathogens as a result of their synergistic infections $[2,4]$.

() Institute of Molecular Biology and Genetics, NAS of Ukraine, 2011
SMV particles are flexuous filaments approximately $750 \mathrm{~nm}$ long and 15 to $18 \mathrm{~nm}$ in diameter. Like other potyviruses SMV contains a monopartite, singlestranded, positive-sense RNA genome of about $9.6 \mathrm{~kb}$. There is a VPg (viral protein genome-linked) covalently bound to its $5^{\prime}$ end and a poly-A tail at the $3^{\prime}$ end. SMV genome encodes one large polyprotein, which is subsequently cleaved at least into 10 mature proteins by virus-encoded proteases $[2,5,6]$. Recently, an additional $25-\mathrm{kDa}$ protein has been discovered in potyviruses. This protein is derived from a frameshift on the P3 cistron [7].

Numerous SMV isolates have been reported all over the world. In the United States, a number of SMV isolates were classified in seven strain groups (G1-G7) based on the symptoms developed in a set of various resistant soybean cultivars (Table 1) [2, 8]. This diffe- 
Table 1

Differential responses of soybean cultivars to field-collected isolate and reference strains of Soybean mosaic virus

\begin{tabular}{|c|c|c|c|c|c|c|c|c|c|}
\hline \multirow{2}{*}{ Cultivar/line } & \multirow{2}{*}{ Genotype } & \multicolumn{8}{|c|}{ Reaction to SMV strain or isolate ${ }^{\#}$} \\
\hline & & G1* & $\mathrm{G} 2 *$ & G3* & G4* & G5* & G6* & $\mathrm{G} 7 *$ & $\mathrm{UA} 1 \mathrm{Gr}$ \\
\hline Essex & $r s v$ & $\mathrm{~S}$ & $\mathrm{~S}$ & S & $\mathrm{S}$ & $\mathrm{S}$ & $\mathrm{S}$ & $\mathrm{S}$ & $\mathrm{S}$ \\
\hline Tousan 50 & $R s v 1-n$ & $\mathrm{~N}$ & $\mathrm{~N}$ & $\mathrm{~S}$ & $\mathrm{~S}$ & $\mathrm{~N}$ & $\mathrm{~N}$ & $\mathrm{~S}$ & $\mathrm{~N}$ \\
\hline Ogden & $R s v 1-t$ & $\mathrm{R}$ & $\mathrm{R}$ & $\mathrm{N}$ & $\mathrm{R}$ & $\mathrm{R}$ & $\mathrm{R}$ & $\mathrm{N}$ & $\mathrm{R}$ \\
\hline Raiden & $R s v 1-r$ & $\mathrm{R}$ & $\mathrm{R}$ & $\mathrm{R}$ & $\mathrm{R}$ & $\mathrm{N}$ & $\mathrm{N}$ & $\mathrm{R}$ & $\mathrm{R}$ \\
\hline Marshall & $R s v 1-m$ & $\mathrm{R}$ & $\mathrm{N}$ & $\mathrm{N}$ & $\mathrm{R}$ & $\mathrm{R}$ & $\mathrm{N}$ & $\mathrm{N}$ & $\mathrm{N}$ \\
\hline York & $R s v 1-y$ & $\mathrm{R}$ & $\mathrm{R}$ & $\mathrm{R}$ & $\mathrm{N}$ & $\mathrm{S}$ & S & $\mathrm{S}$ & $\mathrm{R}$ \\
\hline PI 96983 & $R s v 1$ & $\mathrm{R}$ & $\mathrm{R}$ & $\mathrm{R}$ & $\mathrm{R}$ & $\mathrm{R}$ & $\mathrm{R}$ & $\mathrm{N}$ & $\mathrm{R}$ \\
\hline Harosoy & $R s v 3$ & $\mathrm{~S}$ & $\mathrm{~S}$ & $\mathrm{~S}$ & $\mathrm{~S}$ & $\mathrm{R}$ & $\mathrm{R}$ & $\mathrm{R}$ & S \\
\hline V94-5152 & Rsv4 & $\mathrm{R}$ & $\mathrm{R}$ & $\mathrm{R}$ & $\mathrm{R}$ & $\mathrm{R}$ & $\mathrm{R}$ & $\mathrm{R}$ & $\mathrm{R}$ \\
\hline PI 264555 & $R s v 1-k$ & $\mathrm{R}$ & $\mathrm{R}$ & $\mathrm{R}$ & $\mathrm{R}$ & $\mathrm{N}$ & $\mathrm{N}$ & $\mathrm{N}$ & $\mathrm{R}$ \\
\hline Suweon 97 & $R s v 1-h$ & $\mathrm{R}$ & $\mathrm{R}$ & $\mathrm{R}$ & $\mathrm{R}$ & $\mathrm{R}$ & $\mathrm{R}$ & $\mathrm{R}$ & $\mathrm{R}$ \\
\hline
\end{tabular}

${ }^{\#} \mathrm{R}$ - resistant (symptomless); $\mathrm{N}$ - necrotic (systemic necrosis and local lesion); $\mathrm{S}$ - susceptible (systemic mosaic). *Disease responses were analyzed by Chen et al. [2].

rential system is by far the most recognized and widely used. Similarly, there were five strains (A to E) reported in Japan and 21 strains (SC1 to SC21) - in China [9, 10]. It is interesting that new SMV isolates capable of overcoming host resistance have been identified [11, 12]. Different types of reaction of susceptible and resistant cultivars are the result of specific interaction between the soybean $R$ gene product and the virus avirulence $(A v r)$ gene product $[13,14]$. Inheritance studies have shown that in most cases the virus resistance in soybean is controlled by a single dominant gene. Three independent loci ( $R s v 1, R s v 3$, and $R s v 4$ ) have been reported for SMV resistance $[15,16]$.

Numerous studies have been undertaken to understand the mechanisms that drive the evolution and geographical distribution of plant viruses. The aim was to unravel phylogenetic relationships among virus isolates as they continue to evolve through genetic exchanges (recombination between different viral RNA molecules) or accumulation of mutations $[17,18]$. As more and more SMV isolates are sequenced, the phylogenetic relationship and molecular variability can be studied. Construction of the first SMV phylogenetic trees for the full-length genome or for its single genes ( $P 1$,
HC-Pro and $C p$ ) sequences, allowed dividing SMV strains and isolates into distinct phylogenetic groups and subgroups $[2,11,19]$.

In Ukraine, the diseases caused (presumably) by SMV were first reported in 1938. Later, in the early 1960 's, SMV was identified on soybean field in eastern and southern regions [20]. Since then, contrary to intensive investigation of SMV strain diversity in many countries, in Ukraine, one of the biggest agrarian areas in Europe, no survey was carried out [21].

In the present study we have collected and biologically purified five SMV isolates from breeding plots in Vinnitsa region of Ukraine. We have conducted pathogenicity tests and analyzed phylogenetic relationships based on sequences of the coat protein-coding and $P l$-coding regions, to compare Ukrainian isolates of SMV with previously known isolates or strains, and to trace their origin.

Materials and methods. SMV detection, biological purification, $R N A$ extraction, reverse transcription polymerase chain reaction (RT-PCR), DNA sequencing. Leaf samples were collected during 2008-2010 from naturally infected soybean cultivar showing typical mosaic symptoms at the breeding plots of Vinnitsa 
National Agrarian University, Ukraine. Double antibody sandwich enzyme-linked immunosorbent assays (DAS-ELISA) with anti-SMV-IgG («Loewe», Germany) were used for diagnostics of the initial leaf samples from the field, following the manufacturer's instruction. All samples to be tested were inoculated into and maintained in the susceptible cv. «Gribskaya 30 » in a greenhouse. The bean (Phaseolus vulgaris) cv. Topcrop was used to purify SMV isolates from single lesion [9]. All plants were grown in plastic pots $(11 \mathrm{~cm}$ in diameter) with $12 \mathrm{~h}$ photoperiod at $24{ }^{\circ} \mathrm{C}$. Virus inoculum was prepared by homogenizing approximately $0.5 \mathrm{~g}$ of plant tissue with $1.5 \mathrm{ml}$ of inoculation buffer (0.01 M potassium phosphate buffer, $\mathrm{pH} 7.2,0.01 \mathrm{M}$ EDTA) in a sterile, ice-chilled mortar and pestle. The inoculum in a total volume of $50-100 \mu \mathrm{l}$ was rubinoculated onto the carborundum-dusted (600 mesh) unifoliolate leaves.

Within 2-3 weeks post inoculation, total RNA was extracted from virus-infected soybean leaves using the Pure Link RNA Mini Kit («Invitrogen», USA). A pair of primers, forward (SMV-CPf; 5'-CAAGCAGCAAA GATGTAAATG-3') and reverse (SMV-CPr; 5'-GTCC ATATCTAGGCATATACG-3'), was used to prime the amplification of a conserved region (the fragment of $469 \mathrm{bp}$ ) in the coding region of SMV coat protein $(C P)$ [22]. We have also modified and synthesized a pair of primers, forward (SMV-P1f; 5'-AGTCAAATGGCAA CAATCATG-3') and reverse (SMV-P1r; 5'-GGGAGT AGTGCTGAATATCC-3') for the $P 1$ gene amplification (the fragment of $934 \mathrm{bp}$ ) according to the conserved nucleotide sequences in the same region of different SMV strains (G2, G1, N, G4, G3, G7) from the Gen Bank [11]. A one-step RT-PCR was carried out using both M-MuLV Reverse Transcriptase and Taq DNA polymerase («Fermentas», Lithuania). For RT-PCR amplification, $2 \mu \mathrm{l}$ of total RNA was added to $48 \mu \mathrm{l}$ of reaction mixture $(10 \mu \mathrm{l}$ of $10 \times$ PCR buffer, $3.5 \mu$ of $25 \mathrm{mM} \mathrm{MgCl}_{2}, 0.5 \mu \mathrm{l}$ of $10 \mathrm{mM}$ dNTP, $2 \mu \mathrm{l}$ of each forward and reverse primers [10 pmoles $/ \mu \mathrm{l}], 0.25 \mu \mathrm{l}$ of each reverse transcriptase $[20 \mathrm{u} / \mu \mathrm{l}]$ and Taq polymerase [ $5 \mathrm{u} / \mu \mathrm{l}], 34.5 \mu \mathrm{l}$ of $\mathrm{H}_{2} \mathrm{O}$ ). Thermal cycling conditions («Bio-Rad», iQ5 thermocycler, USA) were: 1 cycle of $42^{\circ} \mathrm{C}$ for $45 \mathrm{~min}, 1$ cycle of $94^{\circ} \mathrm{C}$ for $2 \mathrm{~min}, 35$ cycles of $94^{\circ} \mathrm{C}$ for $30 \mathrm{~s}, 55^{\circ} \mathrm{C}$ for $30 \mathrm{~s}, 72^{\circ} \mathrm{C}$ for $1 \mathrm{~min}$, and a final extension at $72{ }^{\circ} \mathrm{C}$ for $10 \mathrm{~min}$. PCR products were resolved on $1.5 \%$ agarose gel. Sequences were determined directly from the PCR products using the dideoxynucleotide termination method and an $\mathrm{ABI}$ Prism 3730 XL DNA Analyzer («Applied Biosystems», USA). All PCR products were sequenced with the primers used to amplify the fragments. The nucleotide sequence data have been submitted to the GenBank database under the following accession numbers: JF431105 ( $C P$ region) and $\mathrm{JF} 803911$ ( $P 1$ region).

Phylogenetic analysis. The reference strains or isolates of SMV, the sequences of which were retrieved from NCBI (National Centre for Biotechnology Information, USA) database and used in our investigations, are listed in Table 2. Multiple sequence alignments were obtained using ClustalW algorithm (http://www. ebi.ac.uk/clustalw/) [23]. Aligned Pl amino acid sequences were visualized and compared using BioEdit sequence alignment editor [24]. Nucleotide and encoded amino acid sequences were edited and similarities were analyzed using MEGA v.5. program [25]. The phylogenetic relationships of the SMV sequences were analyzed by the NJ and ML algorithms implemented in MEGA v.5. program using WMV as the outgroup (Gen Bank Acc. code EU660580). In NJ analysis, the Kimura's two-parameter model and $p$-distance model were applied for nucleotide and amino acid sequence analyses, respectively. For ML method, the Kimura's twoparameter model was used with default settings. For the statistical significance estimation of branching, bootstrap values were calculated using 1000 random replications.

Pathogenicity test of SMV isolates. To determine biological properties of SMV isolates, several differential cultivars, including Essex, «Tousan 50», Ogden, Raiden, Marshall, York, PI 96983, Harosoy, V945152, PI 264555, and «Suweon 97», were grown and inoculated with each isolate as described above. For independent pathogenicity test, 10 plants of each cultivar were inoculated with each isolate. At the same time 5 plants of each cultivar were inoculated only with buffer (mock inoculation) and used as negative controls. Symptom development was monitored for 5 weeks post inoculation and recorded as described by Chen et al. [2]. The seeds of differential soybean cultivars were obtained from USDA Soybean Germplasm Collection, Urbana, Illinois. 
Table 2

Identity (\%) of Plgene and CP gene nucleotide and amino acid sequences between Ukrainian SMV isolate and known strains of this virus

\begin{tabular}{|c|c|c|c|c|c|c|}
\hline \multirow{3}{*}{ Strain or isolate } & \multirow{3}{*}{ Country of origin } & \multirow{3}{*}{$\begin{array}{l}\text { GenBank accession } \\
\text { no. }\end{array}$} & \multicolumn{4}{|c|}{ Similarities to UA1Gr isolate (Ukraine), \% } \\
\hline & & & \multicolumn{2}{|c|}{ JF803911 (PI gene) } & \multicolumn{2}{|c|}{$\mathrm{JF} 431105$ ( $C P$ gene $)$} \\
\hline & & & $\mathrm{nt}^{*}$ & $\mathrm{aa}^{* *}$ & $\mathrm{nt}$ & aa \\
\hline $\mathrm{N}$ & USA & D00507 & 99,3 & 99,4 & 92,6 & 100 \\
\hline VA2 & USA & AF200582 & 99,3 & 99,0 & 100 & 100 \\
\hline WS37 & Korea & FJ640955 & 99,1 & 99,4 & 92,8 & 100 \\
\hline L-RB & Canada & EU871725 & 99,1 & 99,0 & 92,6 & 100 \\
\hline G4 & USA & FJ640979 & 99,0 & 98,4 & 93,0 & 100 \\
\hline WS156 & Korea & FJ640971 & 98,7 & 98,4 & 94,6 & 100 \\
\hline G2 & USA & S42280 & 98,4 & 94,2 & 93,0 & 100 \\
\hline G7H & Korea & FJ807700 & 96,6 & 97,4 & 93,7 & 100 \\
\hline G5 & Korea & AY294044 & 96,7 & 97,1 & 93,7 & 100 \\
\hline G6H & Korea & FJ640981 & 96,6 & 97,4 & 92,1 & 99,3 \\
\hline Severe & China & AJ312439 & 96,6 & 97,1 & 96,4 & 100 \\
\hline G5H & Korea & FJ807701 & 96,3 & 95,5 & 94,4 & 100 \\
\hline $\mathrm{Aa}$ & Japan & AB 100442 & 96,0 & 95,1 & 94,4 & 100 \\
\hline G6 & USA & FJ640980 & 95,8 & 94,2 & 93,0 & 100 \\
\hline G7 & USA & AY 216010 & 95,7 & 95,8 & 92,1 & 99,3 \\
\hline G1 & USA & FJ640977 & 95,7 & 95,5 & 91,7 & 100 \\
\hline G7A & Korea & FJ640982 & 95,6 & 95,5 & 92,1 & 99,3 \\
\hline G3 & USA & FJ640978 & 95,5 & 95,1 & 91,5 & 100 \\
\hline 413 & USA & GU015011 & 88,2 & 88,3 & 94,8 & 100 \\
\hline Sc6 & China & HM590054 & 87,7 & 86,0 & 93,5 & 100 \\
\hline ChGs2 & China & AF200535 & 87,6 & 86,7 & 98,7 & 100 \\
\hline
\end{tabular}

$*_{n t}$ - nucleotide sequence; **aa - amino acid sequence.

Results and discussion. To examine virus infection on soybean plants grown at the breeding plots of Vinnitsa National Agrarian University, field surveys were performed in 2008-2010. Based on the results of these observations we have collected leaf samples from plants of 6 different soybean cultivars («Gribskaya $30 »$, «Dachnyans'ka 1», «Kirovograds'ka 26», Poema, Williams, Syurpriz) showing the most severe viral symptoms, i. e. mosaics, mottling, rugosity and deformation. All collected samples were identified by DASELISA as infected with SMV except one collected from cv. «Dachnyans'ka 1» (data not shown) [21]. Field isolates of SMV maintained in the susceptible cv. «Gribskaya 30» were inoculated onto P. vulgaris cv. Topcrop. By the $7^{\text {th }}$ day, when the necrotic veinal lesions have appeared on primary leaves of Topcrop (Fig. 1 , see inset), they were cut from the leaf and repeatedly inoculated onto Glycine max cv. «Gribskaya 30». In such way five biologically purified isolates of SMV have been recovered.

Five SMV isolates obtained after biological purification of field samples were used for pathogenicity 
test. All tested SMV isolates showed the same reaction patterns on 11 differential cultivars and, therefore, were classified as one pathotype (data for only UA1Gr isolate are shown in Table 1). As shown in Table 1, UA1Gr isolate could not infect such soybeans as Ogden, Raiden, York, PI 96983, V94-5152, PI 264555 and «Suweon 97» carrying resistance genes Rsvl-t, $R s v 1-r, R s v 1-y, R s v 1, R s v 4, R s v 1-k$ and $R s v 1-h$, respectively. However, UA1Gr isolate infected systemically Harosoy plants containing the $R s v 3$ resistance gene, as well as seedlings of susceptible cultivar Essex (Table 1). For «Tousan 50» and Marshall soybeans, local lesions and systemic necroses have developed on all plants approximately by 10 day post inoculation. According to these results, we have concluded that all five isolates belonged to the $\mathrm{G} 2$ pathotype (Table 1).

For subsequent molecular genetic studies we have decided to use only one isolate (UA1Gr) of SMV, because the identical pathogenic properties were shown for all investigated isolates. The products of RT-PCR amplification of SMV RNA, isolated from infected plants of soybean cv. «Gribskaya 30», were of the expected size of $469 \mathrm{bp}$ and $934 \mathrm{bp}$ for $C P$ and $P 1$ genome regions, respectively. To verify their viral origin these RT-PCR products were directly sequenced. The resulting sequences were used as a query for BLASTX analysis against NCBI database (http://blast.ncbi.nlm.nih. gov/). The results of BLASTX search indicated that our sequences correspond to nucleotide positions 8625 to 9069 (central region of $C P$ ) and 129-1056 ( $P 1$ region) in the genome of SMV strain G2. Thus, an identity for the sequences of primers' annealing sites was demonstrated between UA1Gr isolate and reference isolates of SMV from NCBI.

The nucleotide (nt) and amino acid (aa) sequence alignments of the $C P$ region central part and of the whole $P 1$ region were conducted and analyzed by computer-based programs to compare UA1Gr isolate with the known strains of SMV. These alignments showed that the $C P$ nucleotide sequence of the UA1Gr isolate shared 91.5 to $100 \%$ identity with the sequences of other SMV isolates (Table 2). Minimum nt similarity was observed between SMV-UA1Gr and -G3, -G1, -G7, while maximum - between SMV-UA1Gr and -VA2 (Table 2). At the same time, comparison of $C P$ aa sequences showed $100 \%$ identity between SMV-
UA1Gr and most of other SMV isolates except G7, G7A and G6H (Table 2). These data indicated that vast majority of nucleotide substitutions in the central part of $C P$ region were synonymous. It is not surprising because the regulation of viral RNA amplification and the requirement to assemble stable virions impose intense purifying selection pressures on the $C P$ sequences $[6$, 19]. The alignment of the $P 1$ sequences showed that the similarities for different SMV isolates varied within the range of 87.6-99.3\% for nt sequences, and 86-99.4\% for aa sequences (Table 2).

It is interesting, that $P 1 \mathrm{nt}$ sequences of $\mathrm{UA} 1 \mathrm{Gr}$ and VA2 isolates were also found to be the most similar to each other. A higher level of aa tolerated variability in the $P l$ compared to the $C P$-coding regions suggests a larger number of non-synonymous substitutions occurring in the $P l$ region. The $\mathrm{P} 1$ protein is known as the least conserved region of the entire polyprotein of potyvirus $[6,11,18]$.

Comparison of the aligned $\mathrm{N}$ - and C-terminal aa sequences of the $\mathrm{P} 1$ protein between $\mathrm{UA} 1 \mathrm{Gr}$ isolate and the known strains of SMV showed that aa substitutions were conservatively distributed over the entire coding region. However, significant $\mathrm{N}$-terminal variations were found in aa sequences of G2 strains, particularly between aa positions 92 and 100. As shown in Fig. 2, UA1Gr isolate has aa substitution of Asn by Asp at the position 276 contrary to others. Interestingly, nine SMV isolates (UA1Gr, N, VA2, WS37, L-RB, G4, ChGs2, G2, and WS156) have amino acid deletion at the position 198 from the $\mathrm{N}$-terminus, therefore their $\mathrm{P} 1$ protein has only 308 aa, comparing to 309 aa of other strains (Fig. 2). From Fig. 2 it is obvious, that $\mathrm{C}$-terminal region of the $\mathrm{P} 1$ protein of WMV isolate is much more similar to the same region of other SMV isolates, contrary to $\mathrm{N}$-terminal region of this protein. These results are consistent with those of the analyses for other potyviruses, which all contain highly conserved residues responsible for self-cleaving protease activity, exactly at the C-terminal region of the $\mathrm{P} 1$ protein $[2,11,19]$. We have observed no differences in the proteolytic triad composed of His222, Ser263 and PheVal-Val-Arg-Gly between the positions 283 and 287 for all SMV and WMV isolates, except for the substitution of the second Val for Ile in case of Sc6 isolate (Fig. 2). 
Fig. 1 to article by Sherepitko D. V. et al.

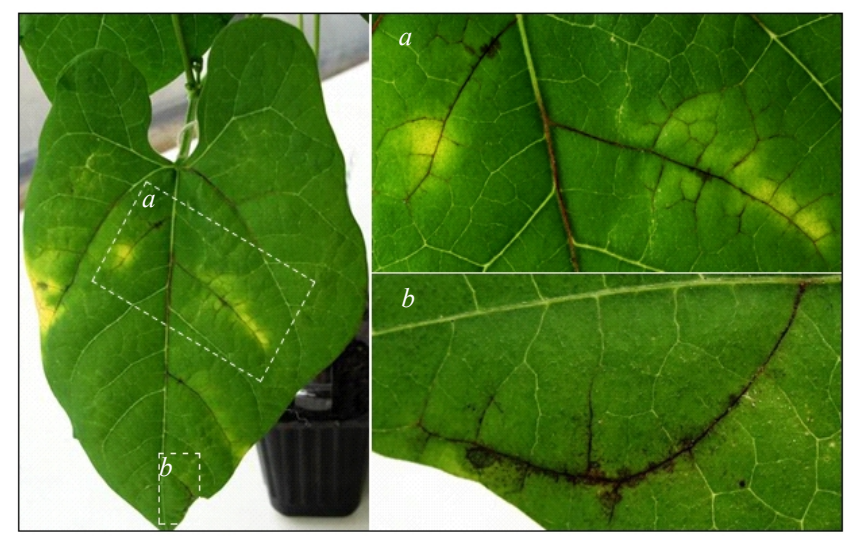

Fig. 1. Necrotic veinal lesions on primary leaves of Phaseolus vulgaris cv. Topcrop (7 days post inoculation). Lesions were cut from the leaf and inoculated into Glycine max cv. "Gribskaya 30» to recover biologically purified isolates of Soybean mosaic virus; $a$ and $b$-zoomed sections

Figures to article by Kordium V. A. et al.

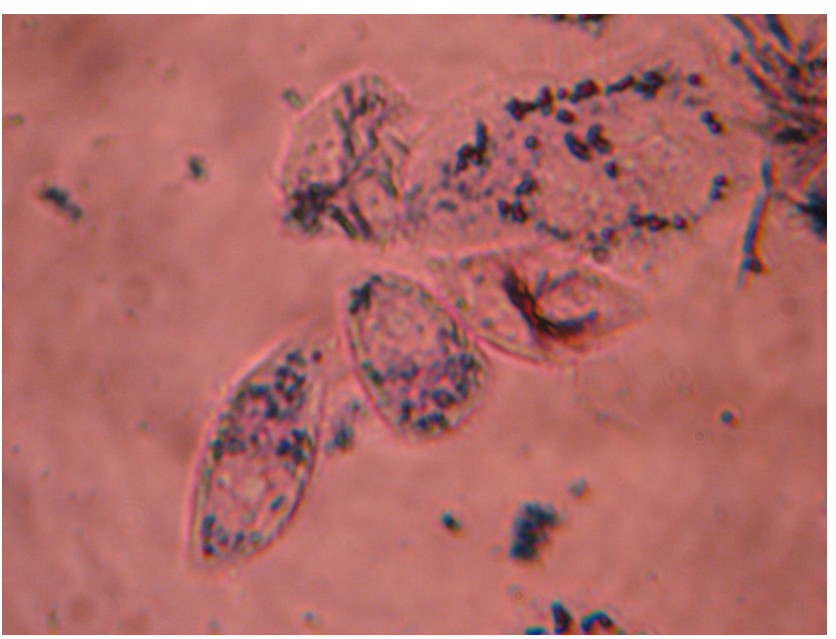

Рис. 1. Образование формазана на везикулах в живой мезенхимальной клетке
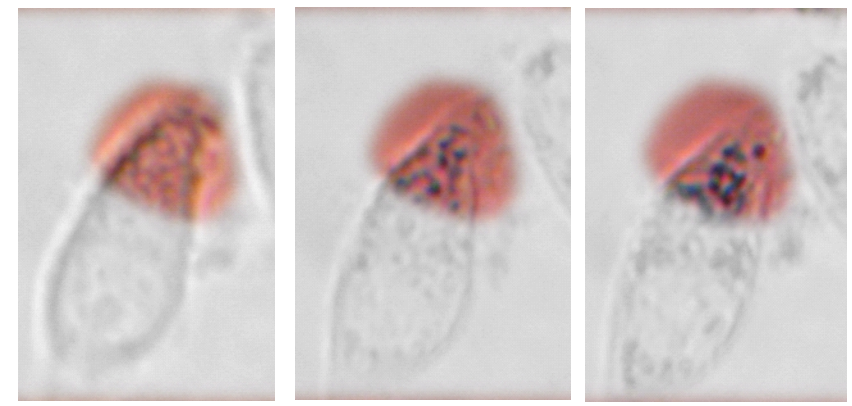

Рис. 2. Кадры видеофрагмента, демонстрирующие образование гранул формазана на движущихся визикулах. Видео доступно на сайте журнала www.biopolymers.org.ua
Figures to article by Kordium V. A. et al.
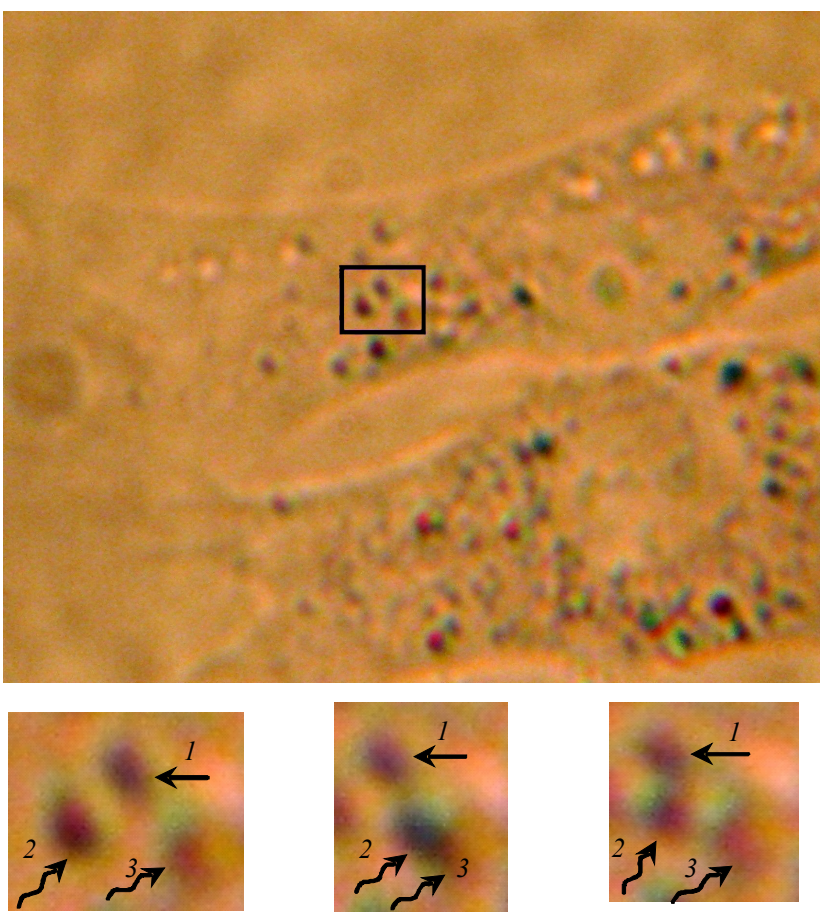

Рис. 4. «Мгновенные» контакты между подвижными везикулами. Видеофрагмент, собранный из последовательно отснятых с интервалом в 5 с кадров, демонстрирует движение везикул, при котором могут возникать кратковременные контакты между ними. Внизу представлены три последовательных (с интервалом в 5 с) кадра, где зафиксированы изменения взаимного расположения везикул, при котором между ними образуется такой контакт. Везикулы визуализировали с помощью интерференционного микроскопа, дающего возможность видеть «неровности» на поверхности клетки, вызванные движением везикул в цитоплазме. Для длительного слежения была создана специальная термостатируемая камера со средой, в которой можно наблюдать за клетками в течение нескольких часов

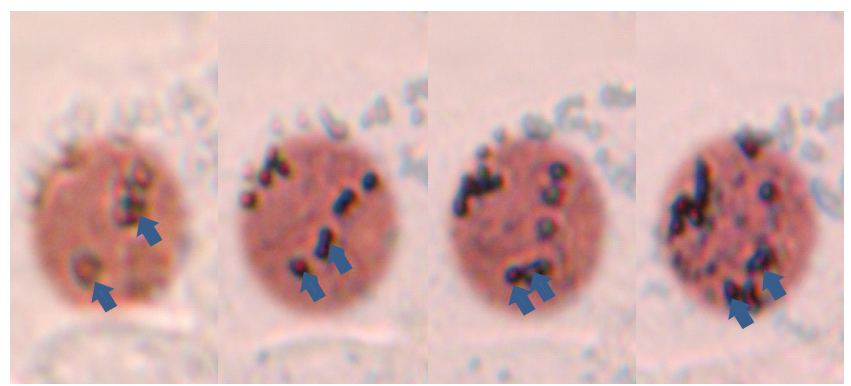

Рис. 5. Кадры видеофрагмента, демонстрирующие контакты различных везикул. Время контакта $225-115=110$ с. Артефакт наложения исключается очень малой глубиной резкости (меньше толщины визикулы). Видео доступно на сайте журнала www.biopolymers.org.ua 


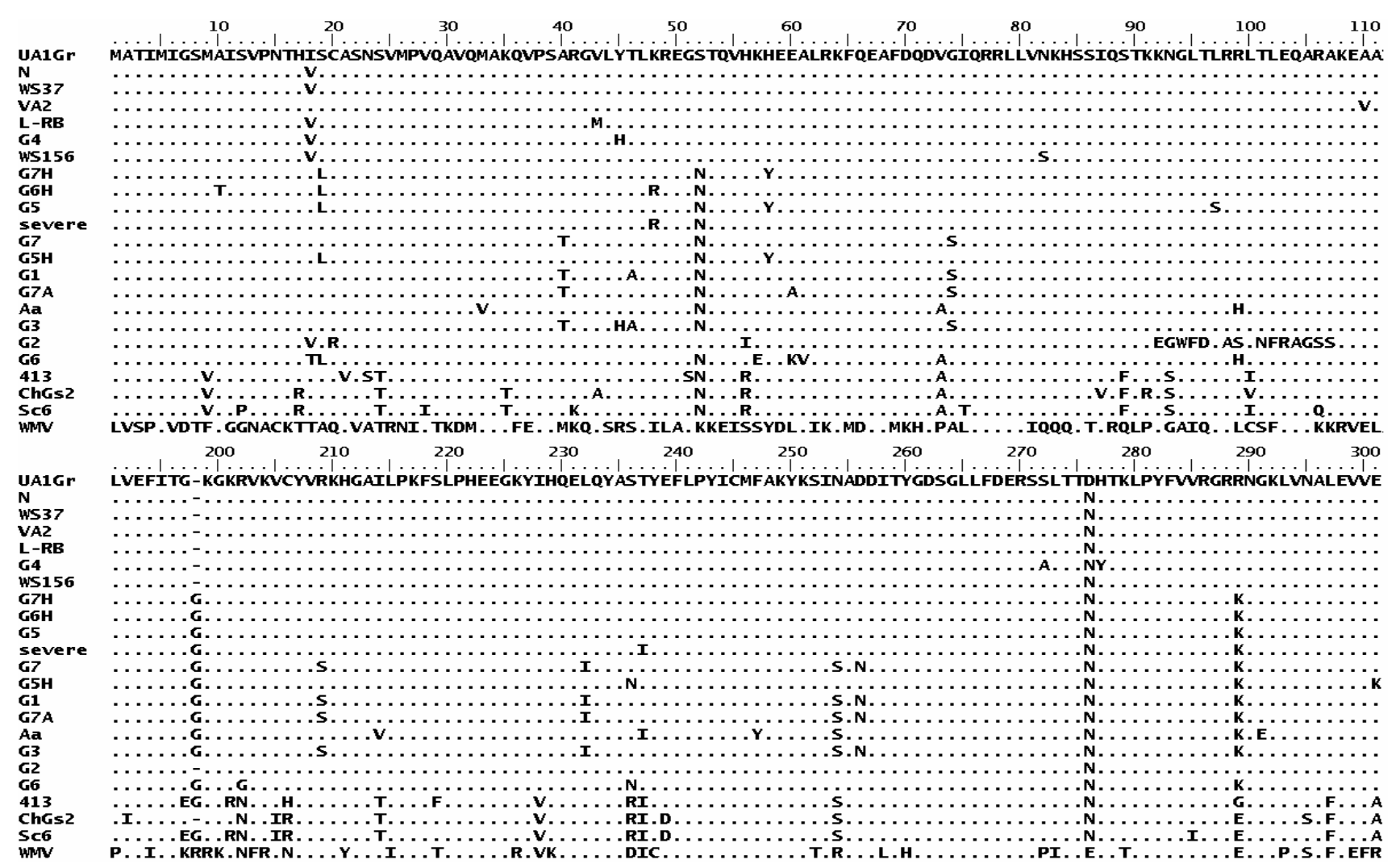

Fig. 2. Comparison of aligned $P 1$ amino acid sequences of Ukrainian isolate (UA1Gr) to those of known strains of SMV. The upper box indicates variable N-terminal region and lower box indicates conserved C-terminal region; «-» indicates lacking amino acid; «.» indicates identical amino acid residues in the alignment; WMV - Watermelon mosaic virus (EU660580)

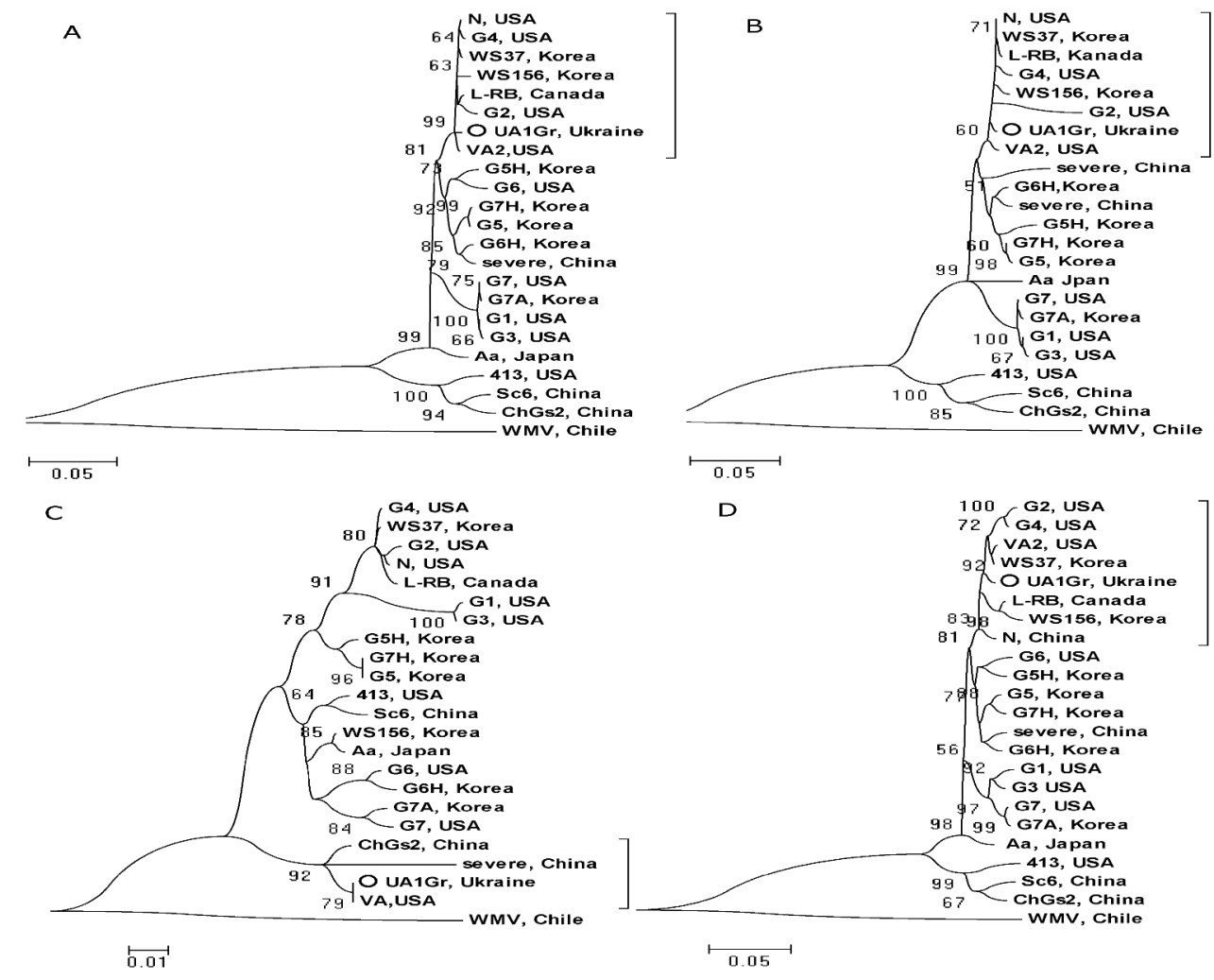

Fig. 3. Phylogenetic analyses for nucleotide sequence $(A)$ and amino acid sequences $(B)$ of $\mathrm{P} 1$ protein region of Ukrainian isolate (UA1Gr) and those of 21 known strains and isolates obtained from the NCBI database (GenBank accession numbers see in the Table 2). Phylogenetic analyses for nucleotide sequence of $C P$ region separately $(C)$ or jointly with $P 1$ region $(D)$. The phylogenetic trees (unrooted) were reconstructed by the ML method applying Kimura's two-parameter model for nucleotide sequence analyses and NJ method with $p$-distance model for amino acid sequence analyses. The $P 1$ and $C P$ sequences of WMV (EU660580) were used as the outgroup. The numbers near the branches indicate bootstrap percentages based on 1000 replications (only values $>50 \%$ are shown). The scale bar shows the number of substitutions per base 
Phylogenetic analysis of the nt and aa sequences conducted for one Ukrainian isolate (UA1Gr) and 21 previously known SMV isolates demonstrated the same general trends observed in the percent identities of the sequences. Using phylogenetic tree for nt sequences of $P 1$ gene reconstructed by the ML method and applying Kimura's two-parameter model (Fig. 3, A), we found that Ukrainian isolate UA1Gr is most closely related to SMV-VA2 and belongs to one clade with G2, G4, WS156, L-RB, N and WS37 isolates (99\% bootstrap). Almost the same result was obtained for aa sequence of the $\mathrm{P} 1$ protein, when $\mathrm{NJ}$ method with $p$-distance model was used (Fig. 3, B). The grouping in the trees obtained for P1 was consistent with the previous whole-genome study of SMV [18]. Such good separation of SMV isolates into genetically distinct groups can be explained by using the highly polymorphic P1 sequence that is not strictly required for viral infectivity. On the other hand, this protein interacts with a varying set of plant factors during the process of host adaptation; therefore P1 is under strong positive selection $[18,19]$. In contrast, ML tree constructed from the central part of the $C P$ regions provided low separation of SMV isolates and was non-informative because the phylogenetic tree for the combined $C P$ and $P 1$ sequences appeared closely similar to that reconstructed for the $P 1$ sequence alone (Fig. 3, $A, C, D$ ). As mentioned above, high conservatism of the $C P$ region is considered to be associated with stronger functional and structural constraints imposed on it $[18,19,26]$.

Our phylogenetic analysis did not show clear relationships between the phylogeny of the isolates and their geographical origin, that can be explained by the recombination events between genomes of SMV isolates $[17,18]$.

Conclusions. Taking into account the investigation of pathogenic properties and the results of phylogenetic analysis, we have concluded that SMV isolates from Ukraine belong to the G2 strain group that is widespread in North America. Since SMV is highly transmissible through seed and by aphids, such results were not surprising. We have assumed that the diversity of parental soybean genotypes obtained from different countries and concentrated on one breeding plot, can be the source of prime viral infection for the newly created cultivars. In our opinion, SMV isolates obtained in this study could be employed by the national breeding programs to create soybeans with durable virus resistance.

\section{Д. В. Шерепітко, І. Г. Будзанівска, В. П. Полішук, А. Л. Бойко}

Часткове секвенуваня і філогенетичний аналіз вірусу мозаїки сої, ізольованого в Україні

Резюме

Мета. Порівняти молекулярно-біологічні властивості украӥнських ізолятів вірусу мозаїки сої (ВМС) із властивостями відомих закордонних ізолятів цьього вірусу, а також прослідкувати їхнє можливе походження. Методи. Механічна інокулячія, полімеразна ланцюгова реакція зі зворотною транскрипцією, секвенування ДНК та філогенетичний аналіз. Результати. На селекційних ділянках у Вінницькій області відібрано та в подальшому очищено n'ять ізолятів ВМС. Показано, шуо всі досліджувані ізоляти ВМС проявляють однаковий спектр реакцій на 11 диференціюючих сортах сої. Філогенетичний аналіз нуклеотидних та відповідних амінокислотних послідовностей генів СР і P1 продемонстрував високу філогенетичну спорідненість між репрезентативним україським (UAlGr) та американським (VA2) ізолятами ВMC, які увійшли до одного кластеру із штамом G2. Результати порівняння нуклеотидних послідовностей підтвердили припущення стосовно того, щзо різні ділянки геному ВМС перебувають під неоднаковим еволюиійним тиском. Висновки. Виділені в Украйні ізоляти ВМС належать до штамової групи $G 2$, ймовірно, походять з території Північної Америки. На наму думку, отримані в даній роботі ізоляти ВМС актуально використовувати у вітчизняних селекиійних програмах для створення вірусостійких сортів сої.

Ключові слова: вірус мозаїки сої, потівірус, Glycine max, послідовності нуклеотидів, філогенетичний аналіз.

\section{Д. В. Шерепитко, И. Г. Будзановская, В. П. Полищук, А. Л. Бойко}

Частичное секвенирование и филогенетический анализ вируса мозаики сои, изолированного в Украине

Резюме

Цель. Сравнить молекулярно-биологические свойства украинских изолятов вируса мозаики сои (ВМС) со свойствами известных иностранных изолятов этого вируса, а также проследить их возможное происхождение. Методы. Механическая инокуляиия, полимеразная цепная реакция с обратной транскрипцией, секвенирование ДНК и филогенетический анализ. Результаты. На селекциионных участках в Винницкой области отобраны и в последующем очищены пять изолятов ВМС. Показано, что все изучаемые изоляты демонстрируют одинаковый спектр реакций на 11 дифференцируюших сортах сои. Филогенетический анализ нуклеотидных и соответствуюших аминокислотных последовательностей генов СР и P1 выявил высокий уровень филогенетического родства между репрезентативным украинским (UAlGr) и американским (VA2) изолятами ВМC, вошедшими в один кластер со штаммом G2. Результаты сравнения нуклеотидных последовательностей подтвердили предположенипе о том, что разные участки генома ВМС находятся под различным эволючионным давлением. Выводы. Выделенные в Украине изоляты ВМС принадлежат к итаммовой группе $G 2$ и, вероятно, являются привнесенными с территории Северной Америки. На наш взгляд, полученнье в данной работе изоляты ВМС актуально использовать $в$ отечественных селекционных программах для создания вирусоустойчивых сортов сои. 
Ключевые слова: вирус мозаики сои, потивирус, Glycine max, последовательности нуклеотидов, филогенетический анализ.

\section{REFERENCES}

1. Fauquet C. M., Mayo M. A., Maniloff J., Desselberger U., Ball L. A. Virus taxonomy. Classification and nomenclature of viruses. Eighth report of the International Committee on Taxonomy of Viruses.-London: Elsevier, 2005.-1259 p.

2. Chen P., Choi C. W. Soybean mosaic virus // Characterization, diagnosis and management of plant viruses.-Texas: Studium Press, 2006.-P. 389-422.

3. Hill J. H., Bailey T. B., Benner H. I., Tachibana H., Durand D. $P$. Soybean mosaic virus: effects of primary disease incidence on yield and seed quality // Plant Dis.-1987.-71, N 3.-P. 237239.

4. Malapi-Nelson M., Wen R. H., Ownley B. H., Hajimorad M. R. Co-infection of soybean with Soybean mosaic virus and Alfalfa mosaic virus results in disease synergism and alteration in accumulation level of both viruses // Plant Dis.-2009.-93, N 12.P. 1259-1264.

5. Jayaram C., Hill J. H., Miller W. A. Complete nucleotide sequences of two soybean mosaic virus strains differentiated by response of soybean containing the Rsv resistance gene // J. Gen. Virol.-1992.-73, Pt 8.-P. 2067-2077.

6. Urcuqui-Inchima S., Haenni A. L., Bernardi F. Potyvirus proteins: a wealth of functions // Virus Res.-2001.-74, N 1-2.P. 157-175.

7. Chung B. Y., Miller W. A., Atkins J. F., Firth A. E. An overlapping essential gene in the Potyviridae // Proc. Natl Acad. Sci. USA.-2008.-105, N 15.-P. 5897-5902.

8. Cho E. K., Goodman R. M. Strains of soybean mosaic virus: classification based on virulence in resistant soybean cultivars // Phytopathology.-1979.-69, N 5.-P. 467-470.

9. Li K., Yang Q. H., Zhi H. J., Gai J. Y. Identification and distribution of Soybean mosaic virus strains in Southern China // Plant Dis.-2010.-94, N 3.-P. 351-357.

10. Takahashi K., Tanaka T., Iida $W$., Tsuda Y. Studies on virus diseases and casual viruses of soybean in Japan // Tohoku Natl Agric. Exp. Stn. Bull.-1980.-62.-P. 1-130.

11. Choi B. K., Koo J. M., Ahn H. J., Yum H. J., Choi C. W., Ryu K. H., Chen P., Tolin S. A. Emergence of Rsv-resistance breaking Soybean mosaic virus isolates from Korean soybean cultivars // Virus Res.-2005.-112, N 1-2.-P. 42-51.

12. Gagarinova A. G., Babu M., Poysa V., Hill J. H., Wang A. Identification and molecular characterization of two naturally occurring Soybean mosaic virus isolates that are closely related but differ in their ability to overcome Rsv4 resistance // Virus Res.2008.-138, N 1-2.-P. 50-56.

13. Flor H. H. Current status of the gene-for-gene concept // Annu. Rev. Phytopathol.-1971.-9.-P. 275-296.
14. Saghai Maroof M. A., Tucker D. M., Tolin S. A. Genomics of viral-soybean interactions // Genetics and Genomics of Soybean.New York: Springer, 2008.-P. 293-319.

15. Shi A., Chen P., Li D., Zheng C., Zhang B., Hou A. Pyramiding multiple genes for resistance to soybean mosaic virus in soybean using molecular markers // Mol. Breed.-2009.-23, N 1.P. 113-124.

16. Cui $X$., Chen $X$., Wang $A$. Detection, understanding and control of Soybean mosaic virus // Soybean - Molecular Aspects of Breeding.-Rijeka: InTech, 2011.-P. 335-354.

17. Gagarinova A. G., Babu M., Strụmvik M. V., Wang A. Recombination analysis of Soybean mosaic virus sequences reveals evidence of RNA recombination between distinct pathotypes // Virol. J.-2008.-5.-P. 143.

18. Seo J. K., Ohshima K., Lee H. G., Son M., Choi H. S., Lee S. H., Sohn S. H., Kim K. H. Molecular variability and genetic structure of the population of soybean mosaic virus based on the analysis of complete genome sequences // Virology.-2009.-393, N 1.-P. 91-103.

19. Domier L. L., Latorre I. J., Steinlage T. A., McCoppin N., Hartman G. L. Variability and transmission by Aphis glycines of North American and Asian Soybean mosaic virus isolates // Arch. Virol.-2003.-148, N 10.-P. 1925-1941.

20. Moscovets S. M., Kraev V. G., Porembska N. B., Bilyk L. G. Virusy i virusni khvoroby bobovikh kultur na Ukraini.-Kyiv: Naukova dumka, 1971.-136 p.

21. Sherepitko D. V., Boyko A. L., Sherepitko V. V. Indication of local strains of soybean mosaic virus on the identified genotype of soybean under condition of Podillya ragion // Bioresources and viruses: VI Int. Conf. (13-17 Sept. 2010, Kyiv, Ukraine).-Kyiv, 2010.-P. 251-252.

22. Wang R. Y., Ghabrial S. A. Effect of aphid behavior on efficiency of transmission of Soybean mosaic virus by the soybeancolonizing aphid, Aphis glycines // Plant Dis.-2002.-86, N 11.P. 1260-1264.

23. Thompson J. D., Higgins D. G., Gibson T. J. CLUSTAL W: improving the sensitivity of progressive multiple sequence alignment through sequence weighting, position-specific gap penalties and weight matrix choice // Nucleic Acids Res.-1994.-22, N 22.-P. 4673-4680.

24. Tamura K., Dudley J., Nei M., Kumar S. MEGA4: Molecular evolutionary genetics analysis (MEGA) software version 4.0 // Mol. Biol. Evol.-2007.-24, N 8.-P. 1596-1599.

25. Hall T. A. BioEdit: a user-friendly biological sequence alignment editor and analysis program for Windows 95/98/NT // Nucl. Acids Symp. Series.-1999.-41.-P. 95-98.

26. Viel C., Ide C., Cui X., Wang A., Farsi M., Michelutti R., Strumvik $M$. Isolation, partial sequencing, and phylogenetic analyses of Soybean mosaic virus (SMV) in Ontario and Quebec // Canad. J. Plant Pathol.-2009.-31, N 1.-P. 108-113.

UDC 633.34:632.3+ 578 Received 01.06.11 